\title{
EFFECT OF TWO AERATION SYSTEMS ON THE PHYSICOCHEMICAL PARAMETERS DURING COMPOSTING OF THE CATTLE AND POULTRY MANURES
}

\author{
Hanaa Abo Koura(1), Hamdy EL Zemrany ${ }^{(2)}$ and Alaa El-Boraie ${ }^{(2)}$ \\ (1) Soil, Water \& Environ. Res. Institute, Agric. Res. Center "ARC", Giza, Egypt. \\ ${ }^{\text {(2) }}$ Soil Sc. Dept., Fac. of Agric., Menoufia Univ., Egypt
}

Received: Dec. 14, 2019

Accepted: Dec. 30,2019

\begin{abstract}
The evaluation of the most suitable aeration technology for cattle and poultry manures composting was carried out using two identical two piles prepared of both manures. Forced ventilation was employed in one of the piles of each manure, whereas mechanical turning was used in the other two piles. The temperature, $p H, E C$, bulk density, organic carbon, organic matter total nitrogen and $\mathrm{C} / \mathrm{N}$ ratio were investigated at $0,1,7,20,35,50,65$ and 80 days of composting of cattle (CM) and poultry (PM) manures piles under FVS and MTS techniques.
\end{abstract}

In the FVS piles, temperatures degree were 70 and $65{ }^{\circ} \mathrm{C}$ at seven days of composting and remained stable up to 40 days. Whereas, the temperatures of MTS piles, peaked $51.0^{\circ} \mathrm{C}$ and 58.1 at 7 days of composting period for the CM and PM, respectively, it approximately remained stable up to 50 day. The FVS had a significant impact on the content of organic carbon and $O M$, of both poultry and cattle manures, in compared to the MTS. During the composting periods of all piles showed that, the increase in percentage of total nitrogen was mostly observed in 35 day for forced aeration System "FVS" piles with poultry and/or cattle manure. The $\mathrm{C} / \mathrm{N}$ ratio of poultry and cattle manure piles significantly affected with the forced aeration system (Forced Ventilation System "FVS") than with the Mechanically Turned System "MTS".

Key wards: Composting, forced ventilation system, mechanically turned system, Cattle and poultry manures.

\section{INTRODUCTION}

Management of organic wastes has become a global environmental challenge, especially in developing countries (Guo et al., 2016; Onwosi et al., 2017). With the rapid development of intensive agriculture and animal husbandry, the global annual production of livestock manure is expected to reach 0.23 billion tons of nitrogen equivalents by 2030 (Wu et al., 2016). However, if manure is not treated properly it can release pathogenic bacteria, heavy metals, and eutrophic elements such as $\mathbf{N}$ and $\mathbf{P}$ into the soil, air, and groundwater, thereby threatening human health and wider environment (Chen et al., 2017 and Zhang et al., 2018).
Composting systems can be classified as static piles, aerated static piles, turned windrows and aerated turned windrows. Turning the pile can incorporate oxygen, but if the pile lacks porosity, the center of the windrows becomes anaerobic in a matter of minutes. Turned windrow can suffer from lack of moisture in dry climates. Many turners designed today introduce water back into the windrow to maintain conditions favorable for high rate composting (Keener et al., 2001).

The forced air method provides for more flexible operation and more precise control of oxygen and temperature conditions in the pile than would be obtained with a windrow system (Solano et al., 2001). Because composting times 
tend to be slightly shorter and anaerobic conditions can be more readily prevented, the risk of odor is reduced. The applicability of this system (Forced Aerated Piles) for the treatment of organic residue provides it with a significant advantage over the windrow method. Other advantages are superior odor control, more inactivation of pathogenic organisms, and use of less site area. The aerated pile technique exposes all composting materials to more uniform temperature. Capital costs are also lower for the aerated pile system (Nickolas and Young, 2002).

The principal aeration methods providing oxygen during the composting process are: physical mixing of the mass, natural convection and finally forced aeration method. The major concern in the last method is the aeration rate. If the aeration rate is insufficient, oxygen will decrease and the lack of oxygen during composting will result in anaerobic conditions. On the other hand, if the aeration rate is too high, the compost pile will be cooled. Different aeration rates have been used previously for agriculture wastes, e.g., 0.34-1.16 L $\min ^{-1} \mathrm{~kg}^{-1}$ (Nickolas and Young, 2002). Sylla et al. (2003) studied the effect of the number of the vertical pipes for the passive aeration on the composting rate found that the composting rate was increased when increasing in number of perforated pipes placed vertically in the composting bed. Active aeration or forced aeration is another way to reduce labor cost. However, there are many inputs such as blower, electricity and perforate pipe. Forced aeration made the compost pile reached the ambient temperature sooner than passive and natural aeration.

Several parameters have been proposed for evaluating compost maturity and stability (Bernal et al., 2009 and Antil et al., 2012). The maturity of the compost refers to the degree of humification reached while its stability is indicated by the level of remaining microbial activity. It is the maturity of the compost that is the determining factor in its commercialization: one of the problems associated with non-mature compost is that decomposition of the non-stabilized organic matter continues even when the compost has been incorporated into the soil. Main factors affecting the length of the composting process are as follows: $\mathrm{C} / \mathrm{N}$ ratio, moisture, nature of feedstocks, oxygen availability, and composting technology Working under non-optimal $\mathrm{C} / \mathrm{N}$ ratios leads to an extension of the process time If the moisture is very high, the passage of air through the pile may be interrupted as the water can fill the necessary air spaces favoring the anaerobic fermentation (Sharma et al., 1997). If the air supply is not appropriate, the process becomes slower since the growth of microorganisms not suitable for composting can be favored or even the piles can undergo anaerobic fermentation Certain lignocellulosic materials can also slow down the composting process like the woody residues or sawdust due to their recalcitrance to the enzymatic attack of the microorganisms (Zayed and AbdelMotaal, 2005).

The $\mathrm{C} / \mathrm{N}$ ratio has a great influence on the decomposition rate of organic materials in soil A material with narrow $\mathrm{C} / \mathrm{N}$ ratio e.g., fresh manure compared to material with a wider $\mathrm{C} / \mathrm{N}$ e.g., olive pruning, would be much easier for microorganisms to decompose given that it sustain proper supply of $\mathrm{C}$ and $\mathrm{N}$. During the turning process a tyndallization-like process (Gould, 2006) may occur, which can destroy pathogens, spores, and weeds' seeds without affecting composting microbial communities. 
The aims of this study are to investigate the effect of two aeration techniques i.e. Forced Ventilation System (FVS) and Turning Windrow System (TWS) on physical and chemical parameters during the composting of cattle and poultry manure. For this proposes, we designed system for Forced Ventilation System (FVS) to get a good air (oxygen) distribution into the piles.

\section{MATERIALS AND METHODS Composting performance}

An experiment was conducted to study the changes in the physiochemical properties of compost produced from cattle and poultry manures i.e. temperature, $\mathrm{pH}, \mathrm{EC}$, bulk density and the content of total carbon, organic matter and total nitrogen as well as $\mathrm{C} / \mathrm{N}$ ratio during composting processes, under two aeration techniques i.e. Forced Ventilation System (FVS) by means of air compressor pump and Mechanically Turned System (MTS) by turning the pile upside down using a loader. A design of a composting FVS is a 2 polyethylene plastic cages $(1 \mathrm{~m}$ length $\times 0.45$ width $x$ $0.6 \mathrm{~m}$ height), with 4 inches $(10 \mathrm{~cm})$ pipe diameter. Each 4 plastic polyvinyl chloride (PVC) perforated pipes were laid horizontally and vertically in a cage shape, an about 600 holes/cage) (Fig. 1).

\section{Organic materials}

Cattle and poultry manure gathered from the animal \& poultry farms of Faculty of Agriculture Menoufia University, Shibin Elkom City, Egypt, were used in this experiment. The organic materials were transported to the Department of Soil Science greenhouse, Faculty of Agriculture Menoufia University, Shibin Elkom City, where the composting operation took place. The large size gravels fractions were separated from the material which was used for composting. Initially, the moisture content in cattle and poultry manure was 80 and $65 \%$, respectively. These organic materials were maintained at ambient temperature of $22^{\circ} \mathrm{C}$ for 10 days. The characteristics of cattle and poultry manure were determined according to the methods described by Page et al. (1982) and the obtained data were shown in Table (1).

\section{Construction and Composting Preparation}

For the 2 piles of cattle manures, one polyethylene plastic cage (FVS) has been incorporated into a pile and the second pile was left without (MTS). At the same time, other piles were prepared for poultry manure as the aforementioned one, where, one polyethylene plastic cage has been incorporated into a pile (FVS) and the second pile was left without (MTS).

Each pile was pyramidal shape, about $1.2 \mathrm{~m}$ in width at the base and $1.2 \mathrm{~m}$ in height. A compressor air pump (Electromagnetic air Composer, model: ACQ-007, output: $100 \mathrm{l} / \mathrm{min}$ ) is connected to each polyethylene plastic cage (one pile of each organic manures) to improve oxygen supply along the pile (FVS) to the cooling phase and was switched continuously during the entire period of composting. Rubber pipes were also used to join the outlets of the compressor pump to the PVC pipes. One aeration rate, namely $8.6 \mathrm{~m}^{3} \mathrm{~h}^{-1} \mathrm{t}^{-1}$ was used in these experiments. Then, another two piles (one pile for each organic manures) which has been made without the polyethylene plastic cage (MTS). To improve oxygen supply and porosity along these piles, they have been manually turning up every two week to the cooling phase (turned 8 times in 80 days). 
Polyethylene Plastic Cages

( $1 \mathrm{~m}$ length $\times 0.45$ width $\times 0.6 \mathrm{~m}$ height)

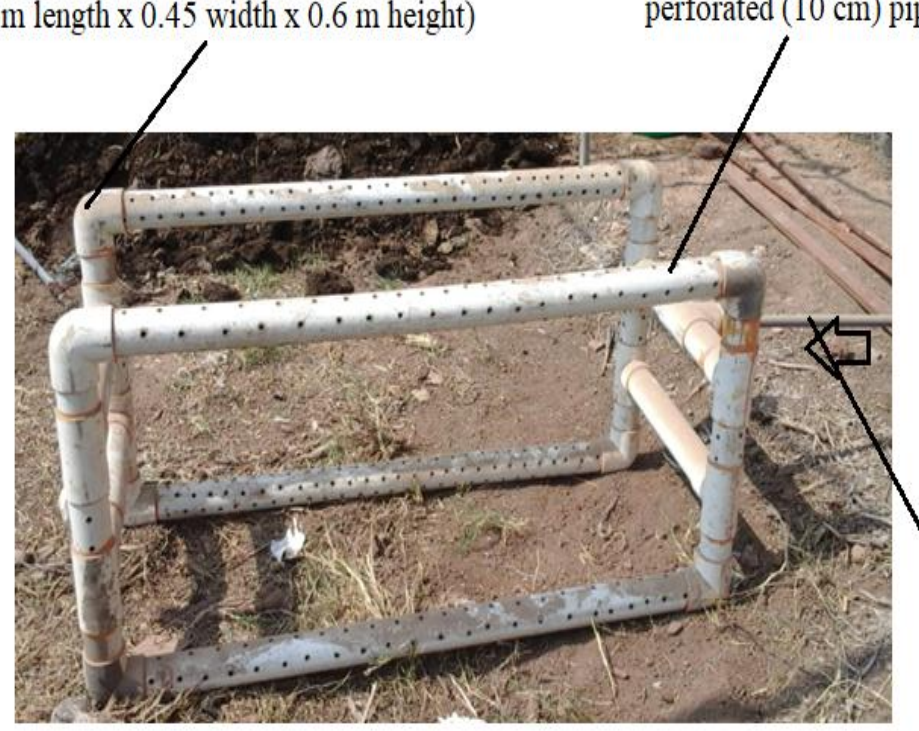

Plastic Polyvinyl chloride (PVC)

perforated $(10 \mathrm{~cm})$ pipe diameter
Rubber pipes used to join the outlets of the

compressor pump

Fig (1): Polyvinyl chloride (PVC) plastic cage: A design of a composting forced ventilation system (FVS).

Table (1): Some chemical properties of cattle and poultry manure used in this study.

\begin{tabular}{|c|c|c|}
\hline Parameters & Cattle manure & Poultry manure \\
\hline pH $(1: 10)$ manure : water susp. & 7.56 & 7.52 \\
\hline EC $(1: 10)$ manure : water extract. $\left(\mathrm{dSm}^{-1}\right)$ & 1.24 & 3.75 \\
\hline TOC & 50.12 & 54.00 \\
\hline TOM $\quad(\%)$ & 80.00 & 86.40 \\
\hline Total N (\%) & 1.33 & 1.80 \\
\hline $\mathrm{C} / \mathrm{N}$ ratio & 37.69 & 30.00 \\
\hline Total P (\%) & 0.62 & 1.86 \\
\hline Total K (\%) & 1.41 & 1.80 \\
\hline Available nutrients & \multicolumn{2}{|c|}{$\mathrm{mg} / \mathrm{Kg}$} \\
\hline $\mathbf{N}$ & 365 & 780 \\
\hline $\mathbf{P}$ & 47 & 54 \\
\hline K & 684 & 713 \\
\hline
\end{tabular}


Each pile of cattle and poultry manures supplemented with $2 \mathrm{Kg}$ of mixed mineral fertilizers/ton of composted materials $\left(1000 \mathrm{~g}\right.$ of $\mathrm{NH}_{4} \mathrm{NO}_{3}+$ $500 \mathrm{~cm}^{3}$ of phosphoric acid $+500 \mathrm{~g}$ $\mathrm{K}_{2} \mathrm{SO}_{4}$ ) and $5 \mathrm{~L}$ of biofertilizer EM1/ton of composted materials (EM1®): Microbial Inoculant for garden and compost needs, is made by the Inst. of Soils, Water \& Environ., ARC", Giza.), as in the following: 1- Pile (1): $750 \mathrm{Kg}$ of cattle manure with incorporated polyethylene plastic cage (Forced Ventilation System). 2- Pile (2): $750 \mathrm{Kg}$ of cattle manure without incorporated polyethylene plastic cage (Mechanically Turned System). 3Pile (3): $750 \mathrm{Kg}$ of poultry manure with incorporated polyethylene plastic cage (Forced Ventilation System). 4- Pile (4): $750 \mathrm{Kg}$ of poultry manure without incorporated polyethylene plastic cage (Mechanically Turned System). Moisture content of each composting pile was monitored and adjusted at maintain 60$65 \%$ during the composting periods. During the composting processes, temperature was measured by long-stem thermometer according to Vomocil (1965), every 7 days.

\section{Sampling}

About $4 \mathrm{~kg}$ sample was collected separately from each pile at $0,1,7,20,35$, 50,65 and 80 days of composting, where each compost sample was gathered from the four different locations from each pile: top and bottom $(50 \mathrm{~cm}$ from the base (down side) and from the surface (upside) of each pile), The samples were divided into two equal parts. The first part was stored at $4{ }^{\circ} \mathrm{C}$ to the biological analysis, where the other was air-dried, ground, passed through a $1 \mathrm{~mm}$ sieve and analyzed for some chemical and physical properties. Composts pH, electrical conductivity (EC), bulk density, total organic carbon (TOC), organic matter content (OM) and total nitrogen
(TN) were determined according to Page et. al. (1982) and Klute (1986).

Analysis of variance (ANOVA) and L.S.D test were applied to analyze the obtained results statistically, according to Steel and Torrie (1980).

\section{RESULTS AND DISCUSSION}

\section{Temperature}

During the composting process an elevated temperature can be created by microorganisms. Therefore, temperature changes during the composting period could be used as a good indication for composing operation. The changes in the temperature of piles under two aeration techniques "FVS" and "MTS" of cattle and poultry manures from the first day (initial time) up to 80 days are shown in Fig (2). The data of temperature was monitored by long-stem thermometer and recorded as the average for different four locations of each pile (top and bottom, 50 $\mathrm{cm}$ from the base and from the surface of each pile). At the beginning of the composting process (zero time), the temperature degree was $22{ }^{\circ} \mathrm{C}$ for all piles.

At the seventh day of the composting process, the temperature was considerably increased up to 51 and $65.1^{\circ} \mathrm{C}$ of cattle manure composting (CM) for the two aeration system i.e. MTS and FVS, respectively. While, the two piles of poultry manure (PM) reached up to $\mathbf{5 8 . 2}$ and $70{ }^{\circ} \mathrm{C}$ for MTS and FVS techniques, respectively. From this moment of composting period all thermophilic microorganisms were enhanced and became more active, meanwhile all the pathogens could be completely inhibited and the composing process occurred in an ideal way and directed to maturation (Putranto and Chen, 2017). 


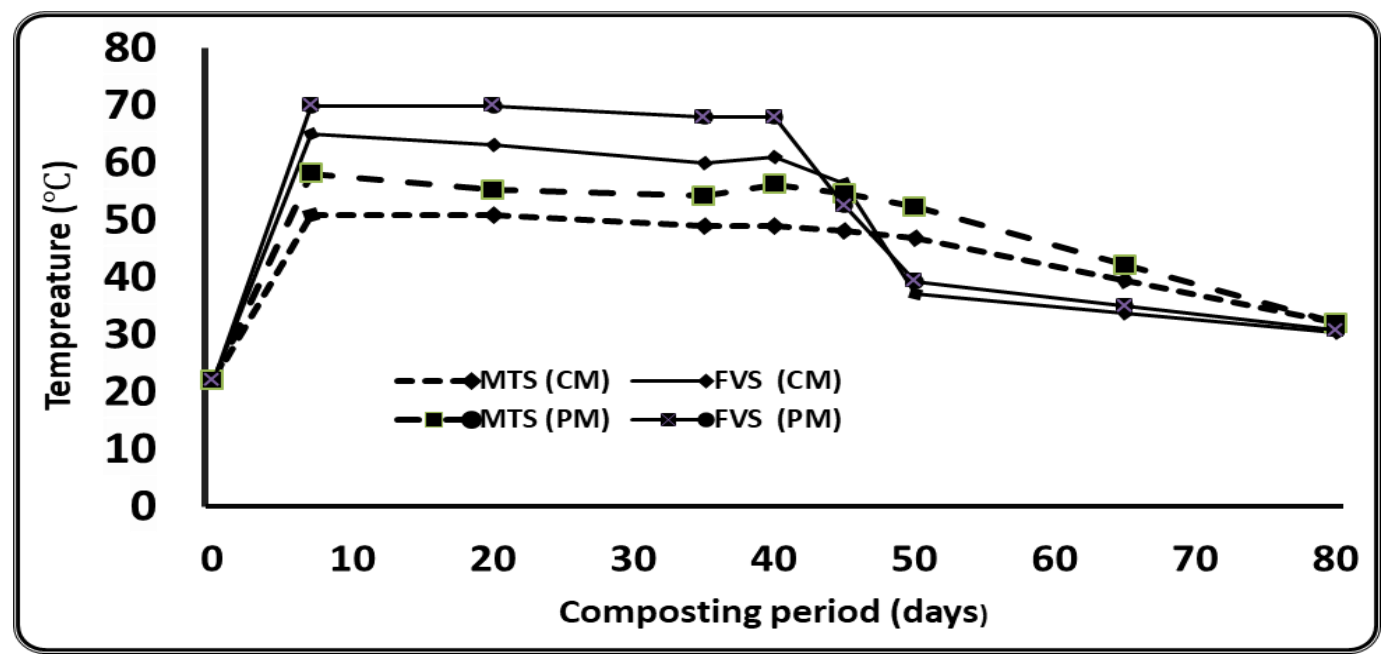

Fig (2): Effect of two aeration systems (Forced Ventilation System "FVS" and Mechanically Turned System "MTS") on the changes in composts temperature $\left({ }^{\circ} \mathrm{C}\right)$ at different time intervals during composting of cattle $(\mathrm{CM})$ and poultry (PM) manures.

At 45 days, of composting period the temperature with aeration technique of the piles of FVS, was decreased, where its was 56.3 and $52.5{ }^{\circ} \mathrm{C}$ for cattle "CM" and poultry manure "PM", respectively. Whereas, the temperature with the MTS technique piles, temperature were slightly decreased, where its were $\mathbf{5 4 . 7}$ and $48.1{ }^{\circ} \mathrm{C}$ for the piles of "PM" and "CM", respectively. In addition, more decrease in temperature degrees of composts was found at 80 days of composting, where the degree of temperature ranged from 30.4 to 30.7 and from 32 to $32^{\circ} \mathrm{C}$ in the piles aerated by FVS and MTS", respectively.

Also, may be observed that the temperature of the poultry manure piles were significant higher increases (L.S.D at $0.05=2.46$ ) than that for the cattle manure piles up at $\mathbf{4 5}$ day of composting periods, under the two aeration systems. In the FVS piles, temperatures degree were 70 and $65{ }^{\circ} \mathrm{C}$ at seven days of composting (Fig. 2) and remained stable up to $\mathbf{4 0}$ days. Thereafter, temperatures were drop and then within a narrow range $\left(56.3\right.$ and $\left.52.5^{\circ} \mathrm{C}\right)$ from period of the 45 days to the end of composting processes up to 80 days.

According to the composting process can be divided into three phases, namely initial activation, thermophilic and mesophilic or maturation phase (Chowdhury et al., 2013). The majority of the organic materials degradation happens during the thermophilic phase. In this phase, microorganisms degrade the readily available compounds in the organic waste. Generally, high microbial activity translates to high degradation of organic waste (Onwosi et al., 2017). This phase is characterized by high temperature in the composting pile due to the heat released from the microbial catabolism of organic waste (Singh and Kalamdhad, 2015). The high temperature achieved in this phase is also crucial for pathogen reduction and sanitization of organic waste. Temperatures above $55^{\circ} \mathrm{C}$ are required to kill the pathogens in the organic waste (Tian et al., 2014 and Putranto and Chen, 2017). Some composting piles are known to reach temperatures as high as $70{ }^{\circ} \mathrm{C}$ during the degradation of animal manure and green waste (Caceres et al., 2016). The end of 
the thermophilic phase and beginning of the maturation phase is indicated by the temperature decrease in the composting pile. As the organic waste stabilizes, the temperature will continue to decrease to ambient air temperature (SanchezMonedero et al., 2018). The temperature decrease also marks the exhaustion of decomposable organic fraction in the waste (Ravindran and Sekaran, 2010).

It was also observed from Fig (2) that different aeriation systems and different in the sources of the used organic manures have a achieved differences temperature peak during the thermophilic phase, which can be attributed to the different $\mathrm{O}_{2}$ levels and different initial $\mathrm{C} / \mathrm{N}$ ratio of the organic waste. Higher temperature in composting pile is an indication of higher microbial activities, which in turn is enhanced by the available carbon sources in the organic manures (Raj and Antil, 2011). However, the efficiency of the forced aeration using the horizontal pipes for aeration is limited by air feeding as it is difficult to ventilate the pipes by the natural convection. Sylla et al. (2003) studied the effect of the number of the vertical pipes for the forced aeration on the composting rate found that the composting rate was increased when increasing in number of perforated pipes placed vertically in the composting bed, therefore, in these study, the Forced Ventilation System "FVS" were designed as cage shape, i.e. the perforated pipes were laid horizontally and vertically.

\section{Compost pH}

Changes of $\mathrm{pH}$ of the four piles as affected by the two aeration systems (FVS and MTS) during composting of cattle (CM) and poultry manures (PM) are illustrated in Fig (3). These data indicate that, $\mathrm{pH}$ values were changed towards acidity over the first week. The average $\mathrm{pH}$ of all piles during this period ranged from 6.28 to 6.60 and from 5.78 to 6.02 for FVS and MTS of poultry and cattle manure, respectively. This was due to the decomposition of organic matter and production of organic and inorganic acids by the activities of microorganisms in the piles. However, the acids themselves are soon utilized by the microbial community, and the $\mathrm{pH}$ rises. The generation of ammonia becomes significant during the rest of the active phase of composting, causing the $\mathrm{pH}$ to remain generally in the weakly alkaline range (Hultman, 2009). Thereafter, at 20 days of composting, compost $\mathrm{pH}$ was increased to 8.80 and $\mathbf{8 . 5 8}$ for FVS piles and to 8.397 .95 for MTS piles, of poultry and cattle manure, respectively.

This higher $\mathrm{pH}$ value may explained by ammonification and mineralization of organic matter through microbial activities (Rasapoor et al., 2009). While the decrease again in $\mathrm{pH}$ values after 35 days of incubation due to the production of $\mathrm{CO} 2$ and organic acids resulting from microbial activity (Varma et al., 2017). Then the $\mathrm{pH}$ values achieved a gradual decrease. The final $\mathrm{pH}$ of the compost piles was found to be 8.05, 7.52, 7.78 and 7.28 for Forced Ventilation System "FVS" and Mechanically Turned System "MTS" of poultry and cattle manure, respectively. The slowing of the rapid rate of $\mathrm{pH}$ increase at the latter stage of composting could be attributed to the volatilization of ammonical nitrogen and the $\mathrm{H}+$ release as a result of microbial nitrification process by nitrifying bacteria (Rasapoor et al., 2009). During the initial phase of composting, reduced $\mathrm{pH}$ and high concentrations of organic acids can occur. During successful composting, the acids are decomposed and the $\mathrm{pH}$ increases. Compared to well-aerated composting, composting at low oxygen levels results in a larger acid production and a slower break-down of acids (BeckFriis et al., 2003). The initial period of low $\mathrm{pH}$ can be significantly reduced if the temperature in the compost stays below $40{ }^{\circ} \mathrm{C}$ until the $\mathrm{pH}$ rises (Smars et al., 2002). 


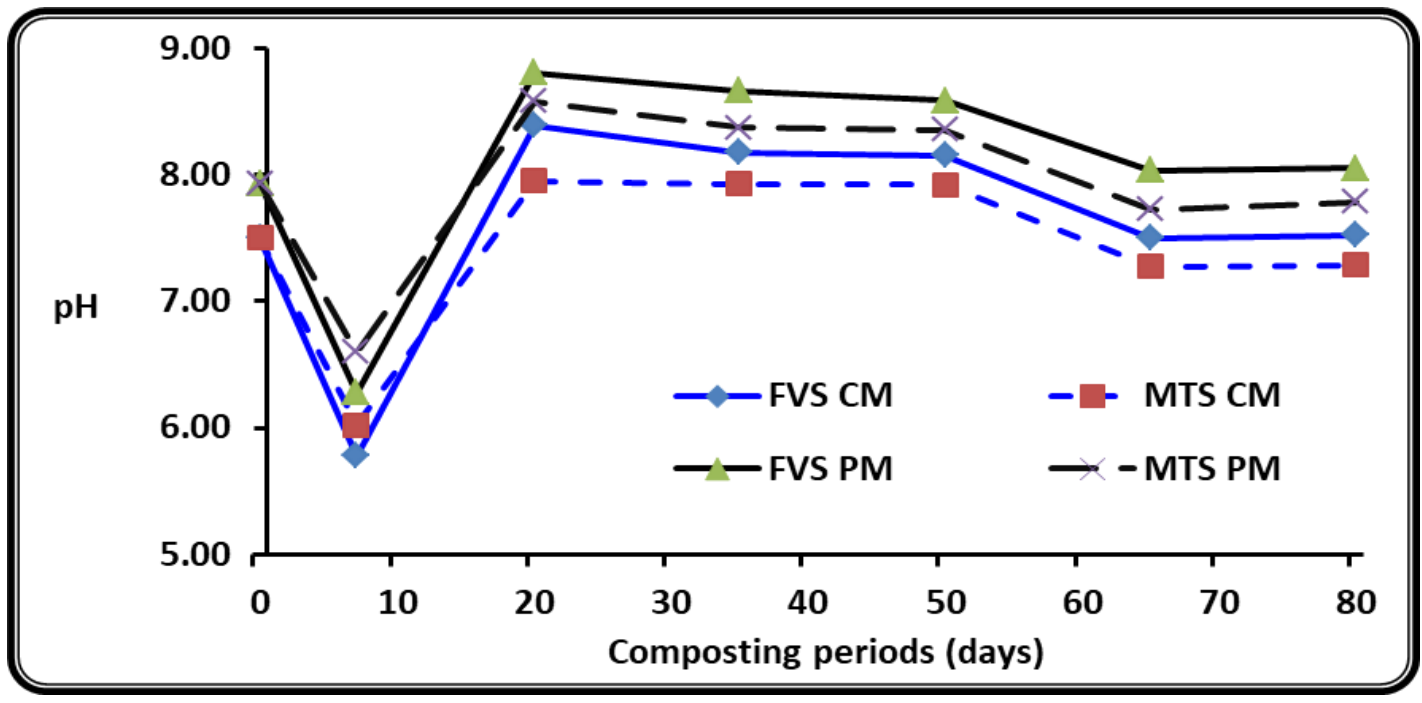

Fig (3): Effect of two aeration systems (Forced Ventilation System "FVS" and Mechanically Turned System "MTS") on composts pH at different time intervals during composting of cattle (CM) and poultry (PM) manures.

\section{Compost electrical conductivity "EC" (dS/m)}

Regarding electrical conductivity (EC) changes in compost piles aerated by FVS and MTS of poultry and cattle manure as recorded in Table, $r$ and illustrated by Fig. (4a) showed that EC values were increased gradually until the end of the composting process where the average EC values at the zero time of the composting process were 3.75 and 1.24 $\mathrm{dS} / \mathrm{m}$ and reached to $7.34,6.58,4.20 \mathrm{dS} / \mathrm{m}$ and 3.50 at the end of composting process of FVS and MTS aeriation systems for poultry and cattle manure piles, respectively. The found increases of "EC" in the composts of poultry manure were higher than those found in cattle manure composts, under the two aeration systems. This result could be attributed to differences in chemical composition and decomposition rate and products of the two manures, especially during the later stage of composting. On the other hand, poultry manure had relatively higher soluble chemical components compared with cattle manure (Table 2).

The increase in EC during the process can be considered due to the release of mineral ions such as phosphate, ammonium, potassium and other cations during the degradation of organic matter. The increase in EC towards the end of composting period was supported by Wong and Fang (2000).

However, it should be noted that, in all composting piles under this study, electrical conductivity values increased during composting. These high values could be due to the effect of the concentration of salts as a result of the degradation of organic matter (Campbell et al., 1997). Table (2) and Figs (3) and (4) showed that, aeration system of FVS significantly (L.S.D at $0.05=0.72$ ) increased EC values of compost compared with these associated. Furthermore, a greater increase in EC values were found at the first stage, but this rate was decreased in later stages, which due to volatilization of ammonia and the precipitation of mineral salts 
(Rasapoor et al., 2009). The increase in EC during the composting process can be considered due to the release of mineral ions such as phosphate, ammonium, potassium and other cations during the degradation of organic matter. The increase in EC towards the end of composting period was supported by Wang et al. (2013).

\section{Compost bulk density $\left(\mathrm{g} / \mathrm{cm}^{3}\right)$}

In respect to bulk density, data in Table (3) and Fig. (4b) indicated that, there was significantly (L.S.D at $0.05=$ 0.058) increase in bulk density of composts under FVS and MT aeration techniques of poultry and cattle manure piles. It increased when the decomposition was progressed by time from zero time of composting process up to $80^{\text {th }}$ day. The average values of composts bulk density was increase from 0.26 and $0.41 \mathrm{~g} / \mathrm{cm}^{3}$ to 0.51 and 0.66 $\mathrm{g} / \mathrm{cm}^{3}$ of poultry and cattle manure with the two aeration systems, i.e. "FVS" and "MTS", respectively. The evaluation of compost quality is based on physicochemical properties such as bulk density, temperature, $\mathrm{pH}$, organic carbon, total nitrogen, ammonium and nitrate ratio, humic substances, and dissolved organic carbon, according to, Mondini et al. (2003 $a$ and $b)$.

Table (2): Effect of two aeration systems (Forced Ventilation System "FVS" and Mechanically Turned System "MTS") on composts electrical conductivity $(E C, \mathrm{dS} / \mathrm{m})$ and Bulk density "BD" $\left(\mathrm{g} / \mathrm{cm}^{3}\right)$ at different time intervals during composting of cattle (CM) and poultry (PM) manures.

\begin{tabular}{|c|c|c|c|c|c|c|c|c||}
\hline \multirow{2}{*}{$\begin{array}{c}\text { Composting } \\
\text { period (days) }\end{array}$} & \multicolumn{6}{|c|}{ Aeration systems } \\
\cline { 2 - 10 } & \multicolumn{2}{|c|}{ FVS } & \multicolumn{2}{c|}{ MTS } & \multicolumn{2}{c|}{ FVS } & \multicolumn{2}{c|}{ MTS } \\
\cline { 2 - 10 } & $\begin{array}{c}\text { EC } \\
\text { dS/m }\end{array}$ & $\begin{array}{c}\text { BD } \\
\left(\mathrm{g} / \mathrm{cm}^{3}\right)\end{array}$ & $\begin{array}{c}\text { EC } \\
\text { dS/m }\end{array}$ & $\begin{array}{c}\text { BD } \\
\left(\mathrm{g} / \mathrm{cm}^{3}\right)\end{array}$ & $\begin{array}{c}\text { EC } \\
\text { dS/m }\end{array}$ & $\begin{array}{c}\text { BD } \\
\left(\mathrm{g} / \mathrm{cm}^{3}\right)\end{array}$ & $\begin{array}{c}\text { EC } \\
\text { dS/m }\end{array}$ & $\begin{array}{c}\text { BD } \\
\left(\mathrm{g} / \mathrm{cm}^{3}\right)\end{array}$ \\
\hline 0 & 3.75 & 0.26 & 3.75 & 0.26 & 1.24 & 0.41 & 1.24 & 0.41 \\
\hline 7 & 4.46 & 0.25 & 3.79 & 0.29 & 1.94 & 0.35 & 1.54 & 0.44 \\
\hline 20 & 5.23 & 0.25 & 4.46 & 0.30 & 2.71 & 0.38 & 1.76 & 0.47 \\
\hline 35 & 5.66 & 0.3 & 4.73 & 0.37 & 3.28 & 0.43 & 2.57 & 0.49 \\
\hline 50 & 6.79 & 0.35 & 5.67 & 0.44 & 4.14 & 0.48 & 3.1 & 0.54 \\
\hline 65 & 7.23 & 0.42 & 6.88 & 0.47 & 4.16 & 0.56 & 3.66 & 0.61 \\
\hline 80 & 7.15 & 0.52 & 6.88 & 0.51 & 4.16 & 0.65 & 3.65 & 0.66 \\
\hline L.S.D. at 0.05 & 0.007 & 0.00001 & 0.007 & 0.00001 & 0.007 & 0.00001 & 0.007 & 0.00001 \\
\hline
\end{tabular}




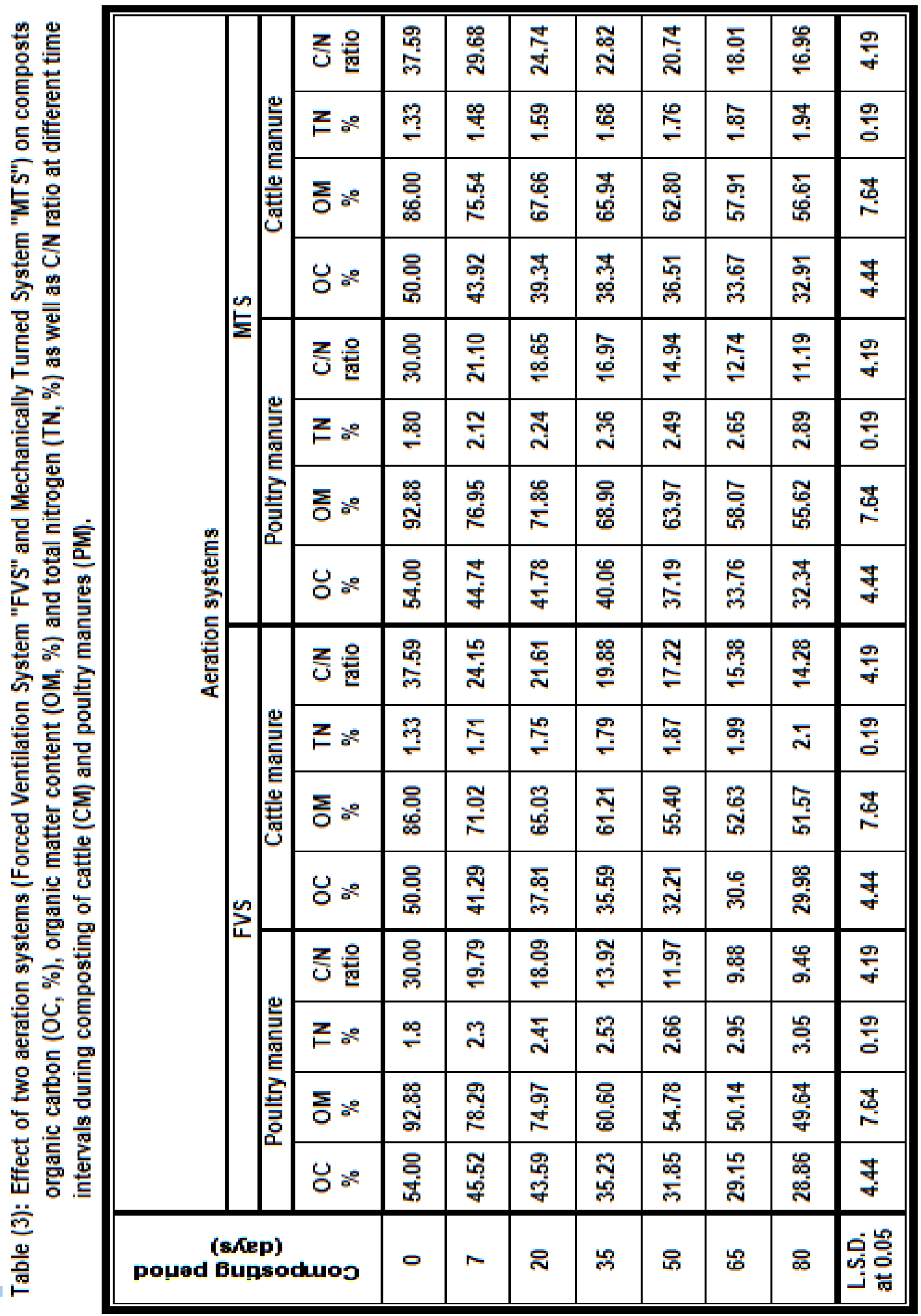




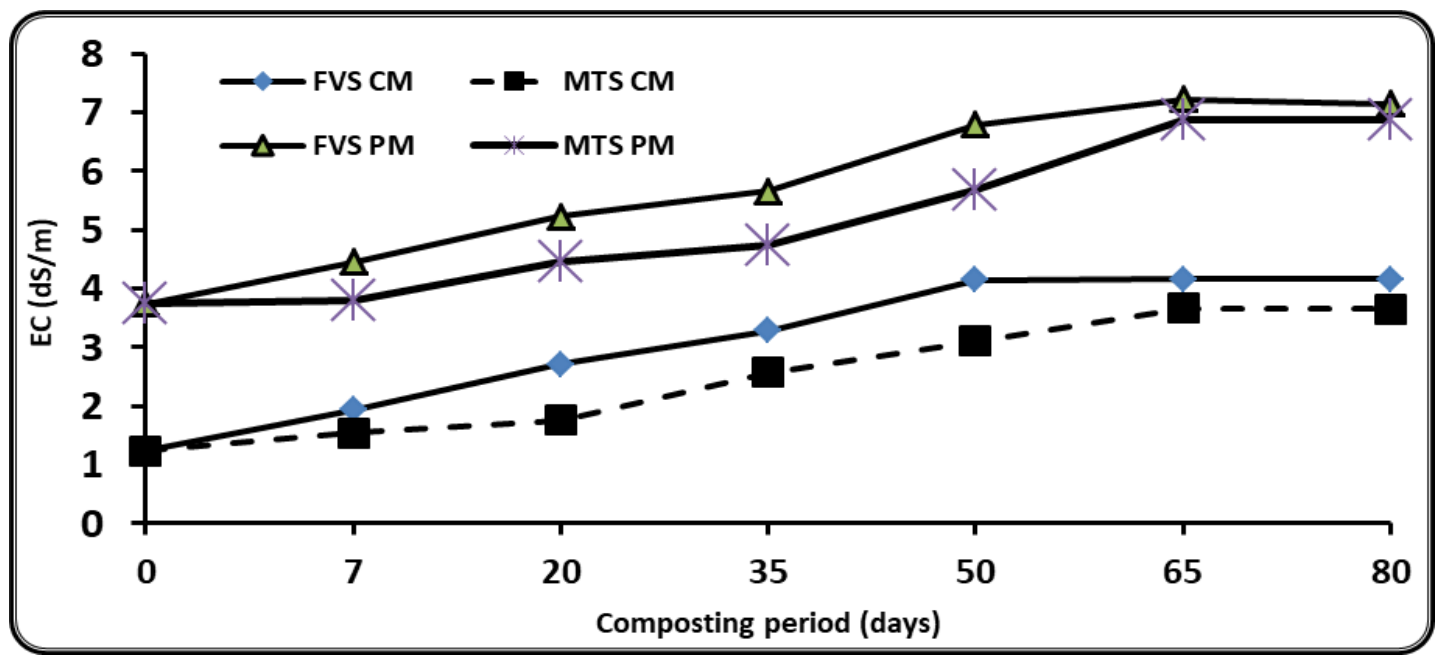


Hanaa Abo Koura, et al.,

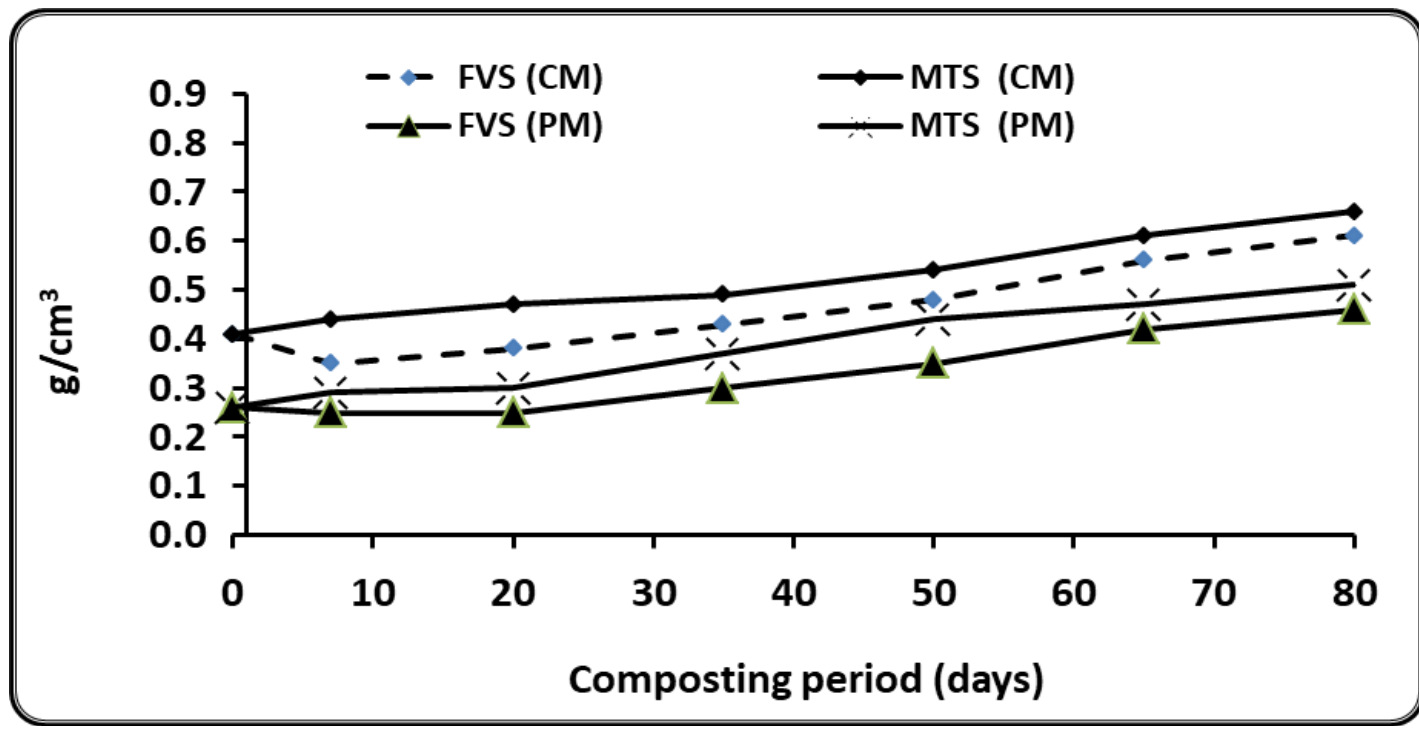

Fig (4a and b): Effect of two aeration systems (Forced Ventilation System "FVS" and Mechanically Turned System "MTS") on compost EC (dS/m) (a) and bulk density $\left(\mathrm{g} / \mathrm{cm}^{3}\right)(\mathrm{b})$ at different time intervals during composting of cattle (CM) and poultry (PM) manures.

\section{Compost organic carbon $(\mathrm{OC})$ and organic matter (OM) content}

Data in Table (3) showed that organic carbon and organic matter content of raw material at zero time of the composting process the cattle and poultry manure were $50.00,86.00 \%$ and $54.00,92.88 \%$, respectively. Then, the content of organic carbon and organic matter appeared a gradual decrease in all types of compounds materials during all composting intervals. In regard to, for the FVS piles, the content of organic - $\mathrm{C}$ and organic matter during the composting intervals from the first day to the $\mathbf{8 0}$ day of the composting process increased from $54.00,92.88 \%$ to 28.86 and $49.64 \%$ in the piles of poultry manure and 50.00 , $86.00 \%$ to 28.98 and $51.57 \%$ in the piles of cattle manure piles. Whereas, for the MTS piles, the contents of organic - C and organic matter during the composting were: $54.00,92.88 \%$ to 32.34 and $55.62 \%$ of poultry manure piles and were 50.00 , $86.00 \%$ to 32.91 and $56.61 \%$ of cattle manure piles. In general, FVS had high and significant impact on the content of organic carbon and OM, of both poultry and cattle manures, in compared to the in MTS. The loss of organic carbon content varied according to the sort and ratio of substrates which formed each pile. The decrease in organic carbon and organic matter may be due to loss of carbon as $\mathrm{CO}_{2}$ via microbial oxidation during the composting process. Carbon (C) and nitrogen $(\mathrm{N})$ are two fundamental nutrients for microbial growth: carbon is used as the energy source and nitrogen is used for protein and nucleic acids synthesis (Li et al., 2011 and Kumar, 2011). A high $C / N$ ratio will reduce the biodegradation rate, whereas a low $\mathrm{C} / \mathrm{N}$ ratio will tend to produce excessive ammonia and volatile fatty acids (VFAs), which may cause inhibition in offensive odors in composting. The initial $\mathrm{OC}$ and OM concentration of poultry manure piles was higher than that of cattle manure pile (Table 3), due to the greater OM content of the PM in comparison with the CM. The values of this parameter decreased during the composting process, manifesting the OM degradation process. 
So, $O C$ and $O M$ losses were substantial during the thermophilic phase in both the aeration systems piles, corresponding to the highest temperature values and the maximum microbial activity. The lowest OM mineralization was observed during the maturation phase, indicating the product stability after the thermophilic phase. The obtained results are in agreement with those reported by Ali (2001). Paredes et al. (2001 and 2002) observed a lower OM degradation during the maturation period of olive mill wastewater composting. Organic carbon and $O M$ degradation produced an increase in EC in both piles (Table 2 and Fig, 4a), due to the production of inorganic compounds and the increasing relative concentration of ions due to the mass loss of the pile (Bustamante et al. (2008). In the later phase of composting, both aeriation system piles of poultry and cattle manures showed a decrease in EC, which could be explained by the volatilisation of ammonia and the precipitation of mineral salts, as Huang et al. (2004) observed when they composted pig manure with sawdust.

\section{Compost content of total nitrogen (TN)}

Table (3), revealed that, the used aeration system FVS had a high significant increase effect on total nitrogen compared that found with MTS with both poultry and cattle manure piles, this was due to the dominance of the optimum temperature range during the process and higher decrease in total organic carbon and organic matter. A long of the composting periods of the poultry and cattle manure with the two aeration systems piles showed that, the increase in percentage of total nitrogen was mostly observed in $\mathbf{3 5}$ day for forced aeration (Forced Ventilation System "FVS") piles with poultry and/or cattle manure, due to higher temperatures during that period. On the contrary, higher decreases in organic carbon contents were monitored during the same period. The nitrogen percentage as a result of composting time is shown in Table 3. This finding was in agreement with the results reported by Pietro and Paola (2004). This increase could be due to either to mineralisation the organic materials consequently enhancing the nitrogen release from decomposed materials or to biological nitrogen fixation by some non-symbiotic microbs in compost. Similar findings were reported by Nasser (2007). Compared with its initial concentration, total nitrogen content increased during composting of the cattle and poultry manures. The increase was probably due to concentration caused by decrease of the carbon substrate resulting from $\mathrm{CO}_{2}$ loss (Bustamante et al., 200)) as a consequence of degradation of nonnitrogenous organic matter (carbohydrates, etc.).

\section{Compost $\mathrm{C} / \mathrm{N}$ ratio}

Data presented in Table (3) showed that, the $\mathrm{C} / \mathrm{N}$ ratio markedly decreased with the progress in the composting process. The $\mathrm{C} / \mathrm{N}$ ratio sharply decreased from the period of 7 to 35 days where its average ranged from 19.79 and 24.15 to 13.92 and 19.88 of Forced Ventilation System "FVS" piles with poultry and cattle manure, respectively, whereas, it were decreased from 21.10 and 29.68 to 16.97 and 22.82 of MTS piles with the same composting manures. From the period of $\mathbf{3 5}$ days to the period of 80 days the found $\mathrm{C} / \mathrm{N}$ ratio was markedly narrow and decreased nearly to 13.92 and 19.88 to 9.46 and 14.28 of FVS piles with poultry and cattle manure, respectively. From the obtained results, it was concluded that, the $\mathrm{C} / \mathrm{N}$ ratio of poultry and cattle manure piles significantly affected with the forced aeration system (FVS) than with the MTS. In all piles, the $\mathrm{C} / \mathrm{N}$ ratio decreased due to mineralization 
of organic matter. Piles forced aerated demonstrated a sharp decrease in $\mathrm{C} / \mathrm{N}$ ratio in comparison with those mechanically turned by Loader (turned weekly). This decrease has been observed also by Bustamante et al. (2008) in different experiments of composting using winery wastes. Finally, the final values of the $\mathrm{C} / \mathrm{N}$ ratio 9.46 and 14.28 in forced aerated piles of poultry and cattle manure, respectively, while it were, 11.19 and 16.96 of the same organic manures piles with mechanically turned by Loader. Suggest that both aerated systems end products composts had reached an acceptable degree of maturation, since they were $<20$, the value suggested by Bustamante et al. (2008).

\section{REFERENCES}

Ali, L. K.M. (2001). Use of improved organic fertilizer as nutrients sources. Ph.D., Thesis, Soil Sci. Dept. Fac. of Agric. Ain Shams Univ.

Antil, RS., D. Raj, RP. Narwal and JP. Singh (2012). Evaluation of maturity and stability parameters of composts prepared from a wide range of organic wastes and their response to wheat. Waste Biomass Valoriz., 4: 95-104.

Beck-Friis, B., S. Smårs, H. Jönsson, Y. Eklind and H. Kirchmann (2003). Composting of source-separated household organics at different oxygen levels: Gaining an understanding of the emission dynamics. Compost Science \& Utilization, 11: 41-50.

Bernal, M.P., J.A. Alburquerque and R. Moral (2009). Composting of animal manures and chemical criteria for compost maturity assessment. A review. Bioresour. Technol. 100: 54445453.

Bustamante, MA., C. Paredes, FC. Marhuenda-Egea, A. Pérez-Espinosa,
MP. Bernal and R. Moral (2008). Cocomposting of distillery wastes with animal manures: Carbon and nitrogen transformations in the evaluation of compost stability. Chemosphere, 72: 551-557.

Caceres, R., N. Coromina, K. Malinska, F.X. Martínez-Farré, M. López and M. Soliva (2016). Nitrification during extended co-composting of extreme mixtures of green waste and solid fraction of cattle slurry to obtain growing media. Waste Manage., (Oxford) 58: 118-125.

Campbell, A.G., R.L. Flok and R. Tripcpi (1997). Wood ash as an amendment in municipal sludge and yard waste composting process. Compost Science and Utilization, 5(1): 62-73.

Chen, W., X. Liao, Y. Wu, J.B. Liang, J. Mi, J. Huang, $H$. Zhang, Y. Wu, Z. Qiao, $X$. $\mathrm{Li}$ and Y. Wang (2017). Effects of different types of biochar on methane and ammonia mitigation during layer manure composting. Waste Manag. , 61: 506-515.

Chowdhury, S., M. Farrell, G. Butler and N. S. Bolan (2013). Stubble retention and soil carbon in long term no-till farming system. SANTFA No-Till Journal. 10(1): 347.

Gould, GW. (2006). History of science spores. J, Appl, Microbiol., 101(3): 507-513.

Guo, X., J. Huang, Y. Lu, G. Shan and Q. Li (2016). The influence of flue gas desulphurization gypsum additive on characteristics and evolution of humic substance during co-composting of dairy manure and sugarcane pressmud. Bioresour. Technol., 219: 169-174.

Huang, G.F., J.W.C. Wong, Q.T. Wu and B.B. Nagar (2004). Effect of $\mathrm{C} / \mathrm{N}$ on composting of pig manure with sawdust. Waste Manage., 24: 805-813.

Hultman, J. (2009). Microbial diversity in the municipal composting process 
and development of detection methods," PhD thesis, Department of Ecological and Environmental Sciences, Faculty of Biosciences and Institute of Biotechnology and Vikki Graduate school in biosciences, University of Helsinki, Finland.

Keener, H.M., D.L. Elwell, K. Ekinci and H.A.J. Hoitink (2001). Composting \& value-added utilization of manure from a high-rise ${ }^{\mathrm{TM}}$ swine finishing facility. Compost Sci. Utiliz., 9: 312-321.

Klute, A. (1986). Methods of Soil Analysis, Part 2: Physical and Mineralogical Properties., Amer. Soc. Agron. Inc. Madison, Wise., USA.

Kumar, S. (2011). Composting of municipal solid waste. Crit. Rev. Biotechnol., 31: 112-36. http://dx.doi.org/10.3109/07388551.201 0.492207.

Li, Y., SY. Park and J. Zhu (2011). Solidstate anaerobic digestion for methane production from organic waste. Renew Sustain Energy Rev., 15:821826. http://dx.doi.org/10. 1016/j.rser. 2010.07.042.

Mondini, C., M. Contin, S. Leita and M. De Nobili (2003b). Response of Microbial Biomass to Air-Drying and Rewetting in Soils and Composting. Geoderma, 105: 111-124.

Mondini, C., M.T. Dell'Abate, L. Leita and A. Benedetti (2003a). An Integrated Chemical, Thermal, and Microbiological Approach to Compost Stability Evaluation. Journal of Environmental Quality, 32: 2379-2386.

Nasser, MMA. (2007). Different sources of organic wastes processing and its effects on some soil properties and on the productivity of wheat and maize crops. Ph.D. Thesis. Fac., Agric., Kafr El-Sheikh, Tanta Univ.

Nickolas, J. and H.K. Young (2002). Material and energy balances in a large scale aerobic bioconversion cell.
Waste Management and Research, 20: 234-242.

Onwosi, C.O., V.C. Igbokwe, J.N. Odimba, I.E. Eke, M.O. Nwankwoala, I.N. Iroh and L.l. Ezeogu (2017). Composting technology in waste stabilization: on the methods, challenges and future prospects. J. Environ. Manag., 190: 140-157.

Page, A.L., R. H. Miller and D.R. Keeny (Ed.) (1982). Methods of Soil Analysis, Part 2 Chemical and Biological Properties. American Society of Agronomy Inc. Mascson, Wisconsin USA.

Paredes, C., M.P. Bernal, A. Roig and J. Cegarra (2001). Effects of olive mill wastewater addition in composting of agroindustrial and urban wastes. Biodegradation, 12: 225-234.

Paredes, C., MP. Bernal, J. Cegarra and A. Roig (2002). Biodegradation of olive mill waste water sludge by its Cocomposting with agricultural wastes. Bioresource Technology, 85:1-8.

Pietro, M. and C. Paola (2004). Thermal analysis for the evaluation of organic matter evaluation during municipal solid waste aerobic composting process. Thermochimica Acta, 413: 209-214.

Putranto, A. and XD. Chen (2017). A new model to predict diffusive self-heating during composting incorporating the reaction engineering approach (REA) framework. Bioresource Technology., 232: 211-221. https://doi.org/10.1016/i.biortech.2017. 01.065

Raj, D. and R.S. Antil (2011). Evaluation of maturity and stability parameters of composts prepared from agroindustrial wastes. Bioresource Technology, 102: 2868-2873.

Rasapoor, M. T., Nasrabadi Kamali M. and H. Hoveidi (2009). The effects of aeration rate on generated compost quality, using aerated static pile 
method. Waste Management, 29: 570573.

Ravindran, B. and G. Sekaran (2010). Bacterial composting of animal fleshing generated from tannery industries. Waste management 30 : 2622-2630.

Sanchez-Monedero, M.A., A. FernándezHernándezb, FS. Higashikawa and M.L. Cayuela (2018). Relationships between emitted volatile organic compounds and their concentration in the pile during municipal solid waste composting. Waste Management, 79: 179-187.

Sharma, V., M. Canditelli, F. Fortuna and G. Cornacchia (1997). Processing of urban and agro-industrial residues by aerobic composting. Energy Convers. Manage., 38: 453-478.

Singh, J. and AS. Kalamdhad (2010). Assessment of compost quality in agitated pile composting of water hyacinth collected from different sources. International Journal of Recycling of Organic Waste in Agriculture, 4(3): 175-183. DOI 10.1007/s40093-015-0097-z

Smars, S., L. Gustafsson, B. Beck-Friis and H. Jönsson (2002). Improvement of the composting time for household waste during an initial low $\mathrm{pH}$ phase by mesophilic temperature control. Bioresource Techn., 84: 237-241.

Solano, M. L., F. Iriarte, P. Ciria and M. J. Negro (2001). Performance characteristics of three aeration systems in the composting of sheep manure and straw. J. Agric. Eng. Res., 79(3): 317-332.

Steel, R. G. B. and J.H. Torrie (1980). Principles and procedures of statutes. 2nd ED. C. Graw-Hill. Inc. P. 633.

Sylla, Y.B., T. Wattanabe, K.J. Cho and M. Kuroda (2003). Effect of the number of the vertical pipes for the passive aeration on the composting rate.
Journal of Water and Environment Technology, (2): 225-230.

Tian, H., G. Chen, C. Lu, X. Xu, DJ. Hayes, W. Ren, S. Pan, DN. Huntzinger and SC. Wofsy (2014). North American terrestrial $\mathrm{CO} 2$ uptake largely offset by CH4 and N2O emissions: toward a full accounting of the greenhouse gas budget. Climatic Change. http://dx.doi.org/ 10.1007/s10584-0141072-9.

Varma, SV., R. Prasad, S. Deb and A. S. Kalamdhad (2017). Effects of aeration during pile composting of water hyacinth operated at agitated, passive and forced aerated condition. Waste Biomass Valor DOI 10.1007/s12649017-9876-2.

Vomocil, J.A. (1965). Porosity. In: Black C.A. (ed). Methods of Soil Aanalysis. Part 1. Physical and mineralogical properties, including statistics of measurements and sampling. Agronomy Monograph Series. American Society of Agronomy. Madison, Wis., USA, 299-314.

Wang, X., A. Slevam, M. Chan and J. Wong (2013). Nitrogen conservation and acidity control during food wastes composting through struvite formation. Bioresour. Technol., 147C: 17-22.

Wong, J. and M. Fang (2000). Effects of lime addition on sewage sludge composting process. Water Research, 34 (15): 3691-3698.

Wu, S., Z. Shen, C. Yang, Y. Zhou, X. Li, G. Zeng, S. Ai and H. He (2016). Effects of $\mathrm{C} / \mathrm{N}$ ratio and bulking agent on speciation of $\mathrm{Zn}$ and $\mathrm{Cu}$ and enzymatic activity during pig manure composting. Int. Biodeterior. Biodegrad., 119: 429-436.

Zayed, G. and H. Abdel-Motaal (2005). Bio-active composts from rice straw enriched with rock phosphate and their effect on the phosphorous nutrition and microbial community in 
rhizosphere of cowpea. Bioresour. Technol., 96: 929-935.

Zhang, C., Y. Xu, M. Zhao, H. Rong and K. Zhang (2018). Influence of inoculating white-rot fungi on organic matter transformations and mobility of heavy metals in sewage sludge based composting. J. Hazard. Mater., 344: 163-168.

تأثير اثنين من أنظمة التهوية على الخواص الفيزيائية والكيميائية أثناء إنتاج الكمبوست من مخلفات الماثية والدواجن الهين

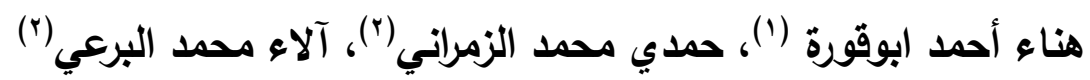

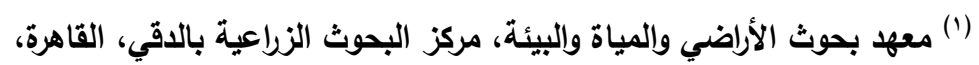

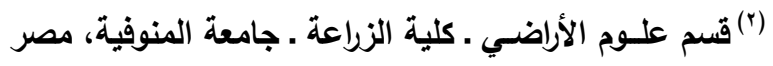
الملخص العربي 
تم إجراء هذا البحث لتقييم نظامين للتهوية الأكثر فعالية لعمل كمبوست من سماد الماثية وسماد الاواجن، حيث تم

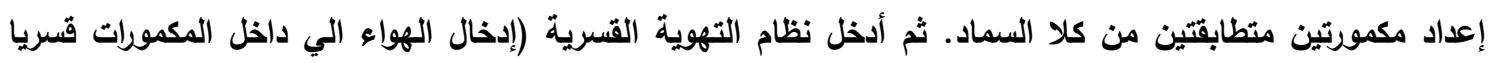
بضاغط هواء كهريائي علي مدار الأريع والعشرين ساعة) في أحد مكمورات كل سماد، في حين تم إدخال نظام التهوية

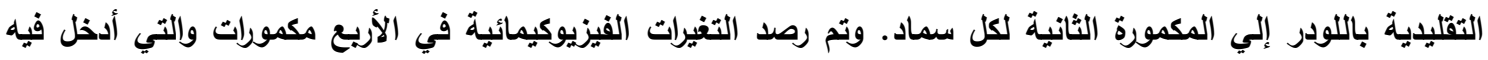

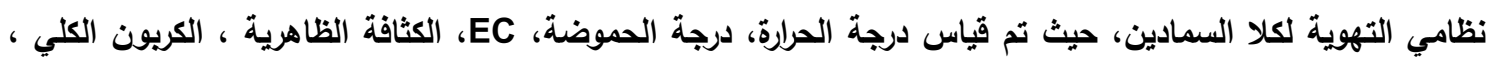

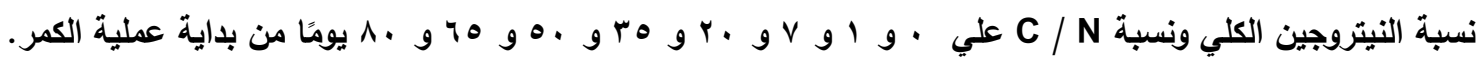
في مكورات نظام التهوية القسرية إرتفعت درجات الحرارة الي · V و هو مْ بعد سبعة أيام من عملية الكمر، وستمرت

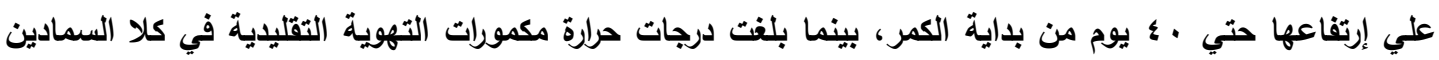

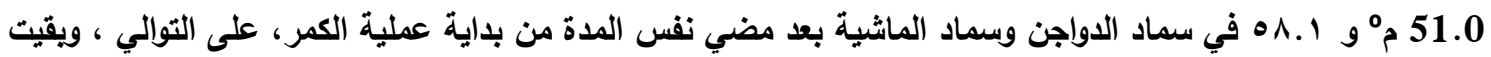

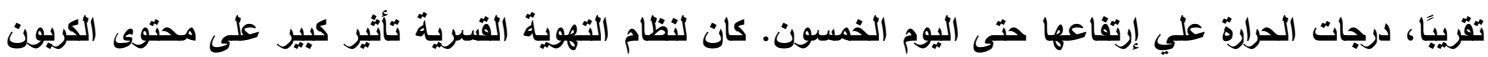

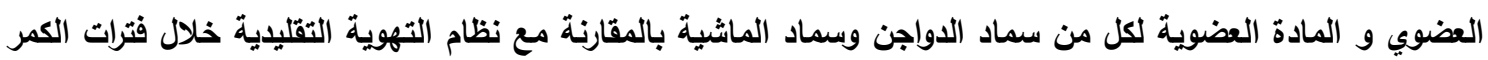

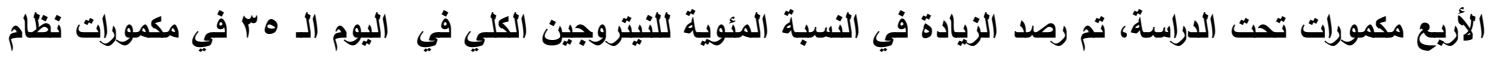

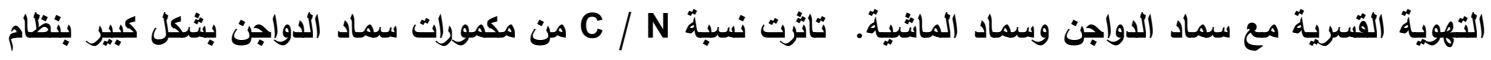
التهوية القسرية مقارنةً بنظام التهوية التقليدية. 